\title{
Comparative effect of high pressure processing and traditional thermal treatment on the physicochemical, microbiology, and sensory analysis of olive jam
}

\author{
By J. Delgado-Adamez ${ }^{a}$, M.N. Franco ${ }^{a}$, J. Sánchez ${ }^{a} \bowtie$, C. De Miguel $^{b}$, M.R. Ramírez ${ }^{a}$ \\ and D. Martín-Vertedor ${ }^{a}$ \\ ${ }^{a}$ Technological Agri-Food Institute (INTAEX). Avda. Adolfo Suárez s/n, 06071. Badajoz. Spain \\ ${ }^{b}$ Vegetal Biology, Ecology and Soil Sciences Department. University of Extremadura. Spain \\ Corresponding Author: jacinto.sanchez@juntaextremadura.es
}

\section{RESUMEN}

Efecto de las altas presiones hidrostáticas y el tratamiento térmico tradicional en las características físicoquímicas, microbiológicas y análisis sensorial de una mermelada de aceituna

En el presente trabajo se valoró el efecto del procesado por altas presiones hidrostáticas (HPP) como método alternativo al tratamiento térmico de pasteurización en la mermelada de aceitunas. Para ello se comparó el efecto de ambos tratamientos sobre el producto procesado y se evaluó su estabilidad durante el almacenamiento en refrigeración, mediante la caracterización de los aspectos físico-químicos, microbiológicos, y sensoriales. Para evaluar el efecto del procesado, se aplicaron dos tratamientos de HPP (450 y $600 \mathrm{MPa})$ y otro de pasteurización térmica $\left(80^{\circ} \mathrm{C}\right.$ durante 20 min), comparándose con el producto no procesado. Las muestras tratadas con HPP 600MPa presentaron, frente al resto de tratamientos una reducción en la presencia de microorganismos, mayor claridad y menor pardeamiento, y una mayor aceptación sensorial. El estudio de la vida útil del producto en refrigeración, indicaría la viabilidad de la aplicación de la tecnología de HPP para obtener alimentos con vida útil similar a la obtenida con el tratamiento tradicional de pasteurización, pero con mejor calidad sensorial.

PALABRAS CLAVES: Altas Presiones Hidrostáticas (HPP) - Análisis sensorial - Mermelada de aceituna - Microbiología - Pasteurización térmica.

\section{SUMMARY}

Comparative effect of high pressure processing and traditional thermal treatment on the physicochemical, microbiology, and sensory analysis of olive jam

In the present work the effect of the processing by high hydrostatic pressures (HPP) was assessed as an alternative to the thermal treatment of pasteurization in olive jam. The effects of both treatments on the product after processing were compared and stability during storage under refrigeration was assessed through the characterization of physicochemical, microbiological and sensory aspects. To assess the effect of processing, two HPP treatments (450 and $600 \mathrm{MPa})$ and thermal pasteurization $\left(80^{\circ} \mathrm{C}\right.$ for $\left.20 \mathrm{~min}\right)$ were applied, comparing them with the unprocessed product. HPP $600 \mathrm{MPa}$ versus the rest of treatments showed a reduction in microorganisms, greater clarity and less browning, and sensory acceptance. The shelf-life of the refrigerated product would indicate the feasibility of the application of the HPP technology for food with similar shelf-life to that obtained with the traditional treatment of pasteurization, but with a better sensory quality.

KEY-WORDS: High Hydrostatic Pressure - Microbiology - Olive jam - Sensory analysis - Thermal pasteurization.

\section{INTRODUCTION}

In recent decades important advances in the application of technologies to food preservation and/or processing, alternative to the conventional thermal treatment processing have been made. Among them, we can mention the electrical pulses of high field strength (Soliva-Fortunya et al., 2009), by supercritical fluid extraction (Reglero et al., 2005), osmotic dehydration (Rastogi et al., 2005) or high hydrostatic pressure (Mor-Mur, 2010). The main requirement to be met by these new technologies is to guarantee the microbiological safety of the products, as well as preserve their sensorial and nutritional characteristics to obtain products with a greater similarity to fresh food (Deliza et al., 2007).

The first research of the effect of high pressure on food was carried out in the 19th century by Hite (1899), who described an increase in the self-life of certain foods such as milk and fruit. However, the scientific development of this technology, its application in the food industry, and the marketing of food are much newer and have occurred in the last two decades. At this point, the application of high hydrostatic pressures (HPP) in the conservation of foods has received special attention as a viable (economically and technologically) alternative to thermal processes (Patterson, 2005) in order to obtain safe food, to maintain better organoleptic or nutritional characteristics and to reduce the use of synthetic preservatives. Processing by high hydrostatic pressure seeks, in the majority of cases, to lengthen the life of foods due to the microbial and enzymatic inactivation caused by pressure and the pressure-temperature while the negative consequences of conventional thermal treatments are avoided (Barbosa-Cánovas et al., 
2008). This type of processing can cause changes in interactions inter and intra-molecular, which can induce conformational changes in macromolecules. In this way the reversible and irreversible denaturation of proteins occurs (Heremans and Smeller, 1998) as well as the enzymatic activation (Asaka et al., 1993) and inactivation (Hendrickx et al., 1998; Buckow et al., 2005). This process is isostatic, i.e., the pressure is transmitted evenly and instantly, and adiabatically, which means that the shape or the size of the food does not matter (Wilson et al., 2008). This prevents food from becoming deformed which could modify its organoleptic properties. The effectiveness of this type of treatment against pathogenic organisms is due to the effect of high pressures on the morphology, structure and functionality of the cellular membranes (alterations of cellular permeability and ion exchange), metabolism and mechanisms of division of microorganisms. The resistance of the microorganisms is highly variable, depending mainly on the type of organism and food matrix involved, for example, the spores are highly resistant to inactivation. Thus, yeasts, fungi and vegetative cells of bacteria may be inactivated by pressures within the range of 200 to $700 \mathrm{MPa}$. Through this type of processing the preservation of the organoleptic and sensorial characteristics of "fresh" or unprocessed foods is facilitated, and the nutritional value is maintained because it is a less aggressive treatment for vitamins and other compounds with antioxidant activity that play a primary role in health (Oey et al., 2007). This is due to the fact that pressure breaks links by bridges of hydrogen but it does not break the covalent links of the compounds, which prevents changes in the chemical composition of foods. This explains why chemical composition and sensory analysis of food treated by high pressures are usually similar to nontreated products, in terms of texture, aroma and color, and changes are lower than those observed from thermal treatments (Mclnerney et al., 2007; Oey et al., 2007).

Olive jam is a product with a traditional preparation that promotes diversification of the olive market and helps to reduce surplus in the sector. Since olives are fruits with a high functional potential due to the presence of oleic acid (Hargrove et al., 2001) and other biological substances such as tocopherols, polyphenols and phytosterols which have antioxidant and anti-inflammatory properties (Acín et al., 2007; Conforti et al., 2009); the search for processing technologies that promote the consumption of these fruits becomes necessary. The application of thermal treatment for the preservation of jam, in some cases, produces a browning of the product and can lead to an unpleasant aspect for consumers; however the application of another type of processing could improve the final quality of the product. High pressure processing has acquired particular importance in recent decades, due to the growing demand for safe products on the part of consumers, with minimum processing and free of additives. The effect of the HPP can vary depending on the conditions of the process (pressure, time of storage, $\mathrm{pH}$ and temperature) and shape of foods (complete, chopped, puree or juice). The food matrix may be altered by these variables; therefore they can influence the effectiveness of the process. The type of plant material (i.e., species) is also important (Wolbang et al., 2008), but not much is known about the impact on the quality of foods produced from olives after HPP treatment. In addition, the studies carried out so far include a study of shelf-life reduced in time. The objective of the present work is to study the effect that HPP treatment and thermal treatment have on microbial safety, color and other sensory characteristics such as appearance, flavor, texture and aroma in an olive jam free of synthetic preservatives; and to assess the stability of the product during 18 months of storage.

\section{MATERIAL AND METHODS}

\subsection{Olive jam processing}

Olive jam was elaborated from commercial green pitted table olives of the Carrasqueña variety packed in brine at a high concentration. The olives were washed and drained in order to obtain a product with a suitable salt content (soaked in water for 90 minutes, changing the water every 30 minutes). Later they were cut with a kitchen robot (Thermomix TM31-1, Vorwerk, Germany) for 10 minutes at maximum power, while adding (500 $\mathrm{mL} \mathrm{Kg}^{-1}$ ) freshly squeezed orange juice as acidifying agent and sugar (450 $\mathrm{g} \mathrm{Kg}^{-1}$ ) as an effective natural additive for preservation, to develop a total of $10 \mathrm{~kg}$ of olive jam. The olive mass obtained was left to macerate for 24 hours and subsequently heated to $100^{\circ} \mathrm{C}$, letting it cook for 30 minutes, stirring frequently until reaching $48^{\circ}$ Brix. Next, the packaging of the samples was done in two different ways depending on the processing applied to the product. For the application of high hydrostatic pressure treatment, the product was packaged to vacuum (Gustav Müller VS 100, Germany) in heatsealed plastic trays of $250 \mathrm{~g}$. For the application of the thermal treatment of pasteurization, the jam was packaged in glass bottles of $125 \mathrm{~g}$, similarly to how it is performed at industrial level. After the thermal pasteurization and the HPP, the samples were stored under refrigeration conditions $\left(4^{\circ} \mathrm{C}\right)$ in the dark for 6 and 18 months.

\subsection{Experimental treatments}

\subsubsection{Thermal treatment: Pasteurization}

Batches of jam, in glass bottles of $125 \mathrm{~mL}$, were pasteurized in a rotary horizontal autoclave of $300 \mathrm{~L}$ (Chaconsa, Murcia, Spain) at $80^{\circ} \mathrm{C}$ for 20 minutes at the center of the product. The temperature was 
recorded with a Dataloger ebro-electronic $\mathrm{GmbH}$ \& Co.KG probe (Ingolstadt Germany).

\subsubsection{High pressure processing (HPP)}

For application of treatments, commercial equipment of high hydrostatic pressures was used (NC hyperbaric Wave 6000/55 Burgos, Spain). It is semi-industrial equipment with a capacity of $55 \mathrm{~L}$, which applies a maximum treatment of $600 \mathrm{MPa} / 6000 \mathrm{bar}$. Initial water temperature in the vessel was $10^{\circ} \mathrm{C}$. Decompression of the product was almost instantaneous. Samples were treated at 450 or $600 \mathrm{MPa}$ for $5 \mathrm{~min}$. Two treatments of HPP were applied; one lot was subjected to an intensity of $450 \mathrm{MPa}$ and the other one at $600 \mathrm{MPa}$, both for a period of 5 minutes. Times to reach $450 \mathrm{MPa}$ or $600 \mathrm{MPa}$ were $188 \mathrm{~s}$ and $230 \mathrm{~s}$, respectively.

\subsection{Analysis}

4 samples per experimental treatment and day of storage were analyzed $(n=4)$ with a total result of 48 samples. Half of the processed samples were analyzed the following day through thermal treatment or HPP, to evaluate the effect of the treatment, while the other half was stored in a cooling chamber $\left(4^{\circ} \mathrm{C}\right)$ in darkness, up to 6 and 18 months to assess the effect of storage and treatments on the processed products. All analyses were performed on fresh samples.

\subsection{1. $p H$, Titratable Acidity (TA) and Soluble Solid Content (SSC)}

The measurement of the $\mathrm{pH}$ was determined with a digital $\mathrm{pH}$ meter Crison micro ph2011 (Barcelona), equipped with probe. C.A.T. TA was assayed by titration with $0.1 \mathrm{~N} \mathrm{NaOH}$ (sodium hydroxide) to an end point of $\mathrm{pH} 8.1$ in a Mettler Toledo DL50 graphix automatic titrator (Mettler Toledo, SAE, Coslada, Madrid, Spain) and expressed as g malic acid per $100 \mathrm{~g}$ of fresh weight. Soluble Solid Content (SSC) was determined with a Mettler Toledo RE40 refractometer (Mettler Toledo, SAE, Coslada, Madrid, Spain) and reported as oBrix. The determinations were made in duplicate for each sample.

\subsubsection{Microbiology analysis}

Microbial analyses were performed in order to test the effectiveness of HPP and thermal treatment at day 1 and the changes during 6 and 18 months of refrigerated storage. The quantification of the mesophilic aerobic microorganisms was performed by ISO 4833: 1991. The microbiological analysis of feasible psychrotrofic microorganisms was determined by Pascual-Anderson and CalderonPascual, 2000. Mould and yeast counts were measured by ISO $7954: 1988$. The determination and quantification of Escherichia coli was performed in half Chromocult (MERCK) incubated for $24 \mathrm{~h}$ at $37^{\circ} \mathrm{C}$. The count of Bacillus cereus was made by Pascual-Anderson and Calderon-Pascual, 2000. For the research and count of sulfite-reducing clostridia of both vegetative forms and sporulated forms the procedure followed the indications given by Pascual-Anderson and Calderon-Pascual (2000). The presence or absence of Salmonella and Listeria monocytogenes was confirmed following EN ISO 6579: 2002 and EN ISO 11290$1: 1996$, respectively.

\subsubsection{Instrumental color}

Instrumental color was measured in a Konica Minolta Spectrophotometer CM-3500d (Aquateknica, S.A., España). The measurement of reflectance was carried out along the $(380 \mathrm{~nm}$ $770 \mathrm{~nm}, \Delta \lambda 2 \mathrm{~nm})$ visible spectrum, geometry $\mathrm{d} / 8$, measuring area $8 \mathrm{~mm}(8 \mathrm{~mm}$ diameter and 10 $\mathrm{mm}$ thick quartz cuvettes) 10th with the primary illuminate D65 observer pattern. The parameters of color corresponding to space CIELab $\left(\mathrm{L}^{*}\right.$, $\mathrm{a}^{*}$ $\left.\& b^{*}\right)$ were determined using the Spectra Magic 3.6.1. software. In addition to the psychophysical parameters, chromaticity $\left[\mathrm{C}^{*}=\left(\mathrm{a}^{\star 2}+\mathrm{b}^{\star 2}\right)^{0.5}\right]$ and angle of the tone or hue [hab $=\operatorname{arc} \tan \left(\mathrm{b}^{*} / \mathrm{a}^{*}\right)$ $(360 / 2 \pi)$ (CIE, 2004) were calculated. Each color measurement was made in triplicate. In order to evaluate changes after processing and changes after storage, color differences $\left(\Delta \mathrm{E}^{*} \mathrm{ab}\right)$, were calculated as the Euclidean distance between two points in three-dimensional space defined by $L^{*}, a^{*}$ and $b^{*}$ using the following equation:

$$
\Delta \mathrm{E}^{*} \mathrm{ab}=\left[\left(\Delta \mathrm{L}^{*}\right)^{2}+\left(\Delta \mathrm{a}^{*}\right)^{2}+\left(\Delta \mathrm{b}^{*}\right)^{2}\right]^{1 / 2}
$$

\subsubsection{Sensory analysis}

Processed olive jams from different experimental treatments were organoleptically evaluated by a select panel of judges with extensive experience in the sensory analysis of food for the research and control of quality (ISO 8586-2: 2008). The number of tasters was 23 , of both sexes (balanced) and between 25 and 55 years old. The evaluations were carried in cabins of individual tests in a tasting room (ISO 8589: 2007). The number of analyses proposed was five, divided into five sessions of one hour each always starting at 10 in the morning. The tasters were given a $20 \mathrm{~g}$ sample of jam on white plastic trays labelled by a random three-digit encoded number. The sensory evaluation was carried out with an elaborated card for this study which evaluated the descriptors: appearance, flavor, texture and aroma of processed jams. For the evaluation of the descriptors, the tasters used an informal scale of $10 \mathrm{~cm}$ long where the score for each processed jam was applied $(0=$ "I don't like it" to $10=$ "I like it very much"). The results of the sensory evaluation were estimated by the median, valid when the coefficient of variation was less than 20. Control samples were not tasted. 


\subsection{Statistical analysis}

The differences associated with the type of processing applied and during storage were analyzed using the ANOVA (one-way analysis of variance) procedure of SPSS, Version 17.0 (SPSS Inc., Chicago, IL). The HSD Tukey test was applied to compare the mean values when ANOVA showed significant differences. Mean values with standard deviations are reported.

\section{RESULTS AND DISCUSSION}

Table 1 shows the values for $\mathrm{pH}$, acidity and the total soluble solid contents (SSC) in the olive jam. Initial control jams and those treated showed a $\mathrm{pH}$ that ranged from 3.92 to 4.00 ; after six months of storage, all analyzed samples had values with a significantly higher $\mathrm{pH}$. This may be due to the development of bacteria that gave rise to a fermentation process that causes an increase in $\mathrm{pH}$, because these microorganisms consume the lactic acid formed and they produce a mixture of acetic and propionic acid which are weaker and cause the $\mathrm{pH}$ increase mentioned before (Cancho et al., 1980). On the contrary, the samples analyzed after 18 months reversed this trend, decreasing the $\mathrm{pH}$ values significantly to the initial values of the day of elaboration, except in HPP 600MPa where $\mathrm{pH}$ was significantly higher. The day of elaboration of the olive jam, the control treatment showed ph values significantly lower than the rest of the treatments. After 6 months of storage there were not significant differences between different experimental treatments, while after 18 months the HPP $600 \mathrm{MPa}$ treatment showed the highest values. Note that $\mathrm{pH}$ values were low enough, for that reason food achieved its stability due to its acidity, apart from inhibiting the activity of various enzymes present in the product, such as hydrolases, lipoxigenases and others (Kalua et al., 2007). Schwartz et al. (2009) indicated regarding olive paste that controlling the microbial count of foods at $\mathrm{pH}$ below 4.5 is possible. The acidity values just show evolution after storage in the case of control samples, being higher after six months. With regard to the differences among treatments, they appeared after six months of storage in which the control samples showed the highest values. However, after eighteen months, the HPP 450MPa showed the most optimal values for this parameter. The SSC content in jams after thermal and HPP (450MPa) treatment showed an increase after storage and this may be due to the consumption of these sugars because of microbial growth, as illustrated in Table 2. The thermal treatment after the elaboration presented the highest value in ${ }^{\circ}$ Brix and HPP $600 \mathrm{MPa}$ samples presented the lowest values and this may be due to the reaction of sugars with other compounds. However, the thermal treated samples presented the same values as the HPP samples $450 \mathrm{MPa}$ after eighteen months of storage, with the lowest values found for the HPP $600 \mathrm{MPa}$. Garcia-Parra et al. (2011) observed significant differences in $\mathrm{pH}$, acidity, and -Brix for nectarine puree due to the type and conditions of processing and the day of elaboration of the product, while after 20 and 60 days of elaboration these differences were equal among experimental treatments. These authors indicate that the decrease in $\mathrm{pH}$ and ${ }^{\circ}$ Brix observed

Table 1

pH, Titrable Acidy (TA) and Soluble Solid Content (SSC) changes in a high pressure and thermal treated olive jam during storage

\begin{tabular}{|c|c|c|c|c|c|}
\hline & Untreated & Thermal & APH (400 MPa) & APH (600 MPa) & \multirow{2}{*}{$\mathbf{P}$} \\
\hline & Mean & Mean & Mean & Mean & \\
\hline \multicolumn{6}{|l|}{ Day 1} \\
\hline $\mathrm{pH}$ & $3,92^{\mathrm{aA}} \pm 0,01$ & $3,97^{\mathrm{bA}} \pm 0,01$ & $4,00^{\mathrm{bA}} \pm 0,02$ & $3,98^{\mathrm{bA}} \pm 0,02$ & 0,01 \\
\hline AT (\%) & $0,30^{\text {ns A }} \pm 0,01$ & $0,30^{N S} \pm 0,01$ & $0,31^{N S} \pm 0,01$ & $0,31^{N S} \pm 0,03$ & 0,64 \\
\hline SST & $38,0^{a b ~ N S} \pm 0,64$ & $39,5^{\mathrm{bB}} \pm 1,45$ & $38,3^{a b B} \pm 0,24$ & $37,3^{\text {a NS }} \pm 0,34$ & 0,02 \\
\hline \multicolumn{6}{|l|}{6 Months } \\
\hline $\mathrm{pH}$ & $4,19^{\mathrm{ns} B} \pm 0,03$ & $4,20^{B} \pm 0,00$ & $4,19^{B} \pm 0,00$ & $4,19^{C} \pm 0,01$ & 0,03 \\
\hline AT (\%) & $0,34^{\mathrm{bB}} \pm 0,01$ & $0,31^{a} \pm 0,01$ & $0,31^{a} \pm 0,00$ & $0,32^{a} \pm 0,01$ & 0,00 \\
\hline SST & $37,6^{\mathrm{ns}} \pm 0,39$ & $37,5^{A} \pm 0,88$ & $37,4^{A} \pm 0,94$ & $37,4 \pm 0,15$ & 0,98 \\
\hline \multicolumn{6}{|c|}{18 Months } \\
\hline $\mathrm{pH}$ & - & $3,99^{\text {a } \mathrm{A}} \pm 0,02$ & $4,00^{\text {a } \mathrm{A}} \pm 0,02$ & $4,07^{\mathrm{bB}} \pm 0,03$ & 0,00 \\
\hline AT (\%) & - & $0,34^{b} \pm 0,01$ & $0,30^{a} \pm 0,01$ & $0,30^{b} \pm 0,17$ & 0,00 \\
\hline SST & - & $36,9^{\text {a } \mathrm{A}} \pm 0,12$ & $36,2^{\text {a } A} \pm 0,12$ & $37,6^{b} \pm 0,20$ & 0,00 \\
\hline
\end{tabular}

Different small letters in the same row indicate statistically significant differences (Tukey's Test, $p<0.05)$ among treatments. Different capital letters in the same column indicate statistically significant statistical differences (Tukey's Test, $p<0.05$ ) during storage. SD: standard deviation. 
Table 2

Microbiological changes (log UFC/gr) of a high pressure and thermal treated olive jam during storage

\begin{tabular}{|c|c|c|c|c|c|}
\hline & Untreated & Thermal & APH (450 MPa) & APH (600 MPa) & \multirow{2}{*}{$\mathbf{P}$} \\
\hline & Mean & Mean & Mean & Mean & \\
\hline \multicolumn{6}{|l|}{ Day 1} \\
\hline Mesophilic & ND & ND & ND & ND & 0,00 \\
\hline Psycrotropic & ND & ND & ND & ND & 0,00 \\
\hline Moulds and yeasts & ND & ND & ND & ND & \\
\hline Escherichia coli & ND & ND & ND & ND & \\
\hline Bacillus cereus & ND & ND & ND & ND & \\
\hline Sulfite-reducing clostridia & ND & ND & ND & ND & 0,00 \\
\hline Salmonella & Abs. & Abs. & Abs. & Abs. & 0,00 \\
\hline Listeria monocytogenes & Abs. & Abs. & Abs. & Abs. & 0,06 \\
\hline 6 Months & & & & & \\
\hline Mesophilic & $2.5^{a} \pm 0.30$ & ND & $1.4^{b} \pm 0.10$ & ND & 0,00 \\
\hline Psycrotropic & $2.0^{a} \pm 0.20$ & ND & ND & ND & \\
\hline Moulds and yeasts & ND & ND & ND & ND & \\
\hline Escherichia coli & ND & ND & ND & ND & \\
\hline Bacillus cereus & ND & ND & ND & ND & 0,00 \\
\hline Sulfite-reducing clostridia & ND & ND & ND & ND & 0,00 \\
\hline Salmonella & Abs. & Abs. & Abs. & Abs. & 0,00 \\
\hline Listeria monocytogenes & Abs. & Abs. & Abs. & Abs. & 0,00 \\
\hline 18 Months & & & & & \\
\hline Mesophilic & - & $1.0^{a} \pm 0.01$ & $1.5^{b} \pm 0.20$ & ND & 0,00 \\
\hline Psycrotropic & - & ND & $1.3^{b} \pm 0.40$ & ND & \\
\hline Moulds and yeasts & - & ND & $1.9 \pm 0.60$ & ND & \\
\hline Escherichia coli & - & ND & ND & ND & \\
\hline Bacillus cereus & - & ND & ND & ND & 0,00 \\
\hline Sulfite-reducing clostridia & - & ND & ND & ND & 0,00 \\
\hline Salmonella & - & Abs. & Abs. & Abs. & 0,00 \\
\hline Listeria monocytogenes & - & Abs. & Abs. & Abs. & 0,00 \\
\hline
\end{tabular}

Different small letters in the same row indicate stastically significant differences (Tukey's Test, $p<0.05)$ among treatments. Abs: absence in 25 g. ND: Non-detected (below detection limit). SD: standard deviation.

during storage in all treatments and the growth of microorganisms in the processing was probably due to a lactic fermentation of sugar that acidified the product. Schwartz et al. (2009) also indicated a decrease in $\mathrm{pH}$ during the storage of an olive paste, indicating that this was probably due to the presence of microorganisms which produce lactic acid and lower the $\mathrm{pH}$.

The effect of the high-pressure and the thermal treatment on the inactivation of microorganisms of olive jam during refrigerated storage is shown in Table 2 . In it the results of microbial inactivation after thermal pasteurization and high hydrostatic pressure treatments in olive jam the day of elaboration and after 18 months are collected. The microbiological analyses carried out the day of elaboration of the jam after the application of experimental treatments, including the control group, indicated that the microorganisms studied were found below the limit of detection of the method and they also showed an absence of pathogens, Salmonella and L. monocytogenes. These results are consistent with those obtained by Sánchez et al. (2012), after the application of HPP and the thermal pasteurization treatment in an olive paste, obtaining an effective inactivation of moulds and yeasts, as well as a reduction in psichrotrophic microorganism counts. GarciaParra et al. (2011) pointed out that the application of HPP and thermal pasteurization treatments were sufficient to maintain microbiological stability in Nectarine puree for more than 60 days of 
storage. After six months of cold storage, control samples experienced an increase in the number of mesophyll and psichrotrophic microorganisms of $2.5 \pm 0.3$ and $2.0 \pm 0.2 \log \mathrm{UFC} \cdot \mathrm{g}^{-1}$ respectively. Likewise, the count of mesophyll in olive jams under HPP 450MPa for 5 min presented a growth of $1.4 \pm 0.1 \mathrm{log} \mathrm{UFC} \cdot \mathrm{g}^{-1}$, indicating that this experimental treatment had a moderate effect on microbial inactivation of this finished product. This result was significantly lower than the one obtained in the control samples, however both are within the value guidelines set in the Codex Alimentarius for the consumption of this product. It is interesting to note that in thermal and HPP 600MPa treatment a microbial proliferation was not observed after six months of cold storage at $4^{\circ} \mathrm{C}$. Sánchez et al. (2012) observed after the cold storage of an olive paste for 1 month, that the microbial counts of aerobic mesophyll, psichrotrophs, Escherichia coli and total enterobacteria held steady in HPP and thermal treatments. Untreated jam (control) samples were ruled out due to a perceptible microbiological deterioration after cold storage for eighteen months. Schwartz et al. (2009) found similar results for spreadable olive paste stored in cold storage and at room temperature. Sánchez et al. (2012) observed an increase in the counts of moulds and yeasts of 4.5 logarithmical units. Therefore, it should be noted that olive jam requires the application of a treatment in order to provide a more commercial life of the product and minimize microbiological risks, since without it, the product does not meet health and hygiene conditions for consumption. For the rest of the evaluated samples, a microbial growth in olive jams under HPP 450MPa, with similar values $(p>0.05)$ to those found in this same treatment after six months of storage was observed. Jams under HPP 600MPa treatment presented the best microbiological quality, as no microorganism was detected, providing a higher microbiological safety than samples thermally treated, with counts of $1.0 \mathrm{log} \mathrm{UFC} \cdot \mathrm{g}^{-1}$. In general, olive jams processed by both HPP and thermal treatment presented a reduction in the counts of microorganisms analyzed with respect to control jams. In addition, the elimination of microorganisms was more intense in treatments at higher pressures (600MPa vs $450 \mathrm{MPa}$ ). This may be due to the fact that the HPP induced morphological, biochemical, and genetic changes in the membrane and the cell wall of microorganisms, which lead to changes in their operation and reproduction (Cheftel, 1992; De Lamo et al., 2004), provoking their death. Thus, this lowest count may also be due to the acidic $\mathrm{pH}$ of the product $(\approx \mathrm{pH} 4)$ (Table 1$)$, which strongly raises organisms subjected to high pressures and favors physiologically compromized microorganisms after HPP treatment not to survive during the subsequent cooling (Carlez et al., 1994; Patterson et al., 1997; Tewari et al., 1999), taking a decisive role in the microbiological stability of this natural product. García-Parra et al. (2011) indicated in nectarine purees, that the HPP 450MPa treatment was the one with the lowest values of microbiological inactivation. In addition, these researchers indicated that the thermal treatment showed the highest microbiological stability at the end of storage.

In general, the olive jam microbiological load was much lower than that found in other agri-food products (olive paste, nectarine puree), prepared by other researchers (Schwartz et al., 2009; GarcíaParra et al., 2011; Sánchez et al., 2012). This may be due to the fact that the previous pre-treatment could have reduced the level of microorganisms before the packaging of the product and the implementation of experimental treatments. In addition, the high concentration of added sugar in the olive jam prepared could have contributed to maintaining the same stability during storage due to the osmotic phenomenon; sugar penetrates the tissues of the fruit and water is released from it until a balance in the concentrations of both is reached. Thus, as a result of water loss in the fruit, water from food is dramatically reduced. This reduction in water in the tissues of the fruit prevents microbial growth and allows for preservation. Micro-organisms, under the effect of the osmotic pressure, lose water and there is a dislocation of the tissues, causing the cells' death. Therefore, the preservation of olive jam occurs due to various factors that act together and increase the shelf life of the food such as the reduction in the water activity of the product by the addition of sugar, the initial thermal treatment that reduces the original microbial load of the jam, the high acidity of the jam (addition of fresh orange juice), the application of pressure temperature treatment after the manufacturing of the product and vacuum packaging.

Changes in the instrumental color of olive jams due to processing and its evolution during storage are shown in Table 3 . In a general way and after six months of storage the clarity parameter $\left(L^{*}\right)$ remained stable for the control treatment as well as for HPP treatments; however, the thermal treated samples and those treated by HPP 450MPa lose clarity after 18 months of storage, this decrease being continuous from the first day of elaboration in the case of thermal treatment and after six months in the case of HPP 450MPa. This decline can be attributed, as García et al. (1999) pointed out, to the oxidation of polyphenols which may entail a higher browning of the samples. Thus, Schwartz et al. (2011) used the value of $L^{*}$ as an indicator of browning in vegetables. These authors observed a decrease in the colorimetric $L^{*}$ parameter in the olive paste during storage, probably due to the oxidation of polyphenols. The chromatic coordinate $\mathrm{a}^{*}$ (red-green) experiences, after six months of storage and comparing to the first day of elaboration, a significant increase in the control samples just as the rest of the samples subjected to different treatments. Similar results were obtained by Krebbers et al. (2003) after subjecting tomato juice to HPP and combined thermal treatments. These authors attributed the increase 
Table 3

Instrumental color changes of a high pressure and thermal treated olive jam during storage

\begin{tabular}{|c|c|c|c|c|c|}
\hline & Untreated & Thermal & APH (450 MPa) & APH (600 MPa) & \multirow{2}{*}{$\mathbf{P}$} \\
\hline & Mean & Mean & Mean & Mean & \\
\hline \multicolumn{6}{|c|}{ Day 1} \\
\hline$L^{*}$ & $44,3^{\mathrm{b} \mathrm{NS}} \pm 0,20$ & $42,4^{\mathrm{aC}} \pm 0,51$ & $44,5^{\mathrm{bB}} \pm 0,20$ & $44,2^{\mathrm{bNS}} \pm 0,49$ & 0,00 \\
\hline$a^{*}$ & $-1,75^{\text {a } A} \pm 0,05$ & $-1,31^{\mathrm{bA}} \pm 0,05$ & $-1,88^{\text {a } \mathrm{A}} \pm 0,11$ & $-1,76^{\text {a } A} \pm 0,17$ & 0,00 \\
\hline$b^{*}$ & $28,8^{\mathrm{b} B} \pm 0,37$ & $25,0^{a \mathrm{~B}} \pm 0,40$ & $28,8^{b c} \pm 0,38$ & $28,9^{\mathrm{bB}} \pm 0,49$ & 0,00 \\
\hline $\mathrm{C}_{\mathrm{ab}}^{*}$ & $28,8^{\mathrm{bB}} \pm 0,37$ & $25,0^{a \mathrm{~B}} \pm 0,41$ & $28,9^{b C} \pm 0,39$ & $28,9^{b c} \pm 0,49$ & 0,00 \\
\hline $\mathrm{h}_{\mathrm{ab}}$ & $93,5^{\mathrm{bB}} \pm 0,07$ & $87,0^{\text {a } A} \pm 0,53$ & $93,7^{\mathrm{bB}} \pm 93,73$ & $93,5^{\mathrm{bB}} \pm 0,35$ & 0,06 \\
\hline \multicolumn{6}{|c|}{6 Months } \\
\hline$L^{*}$ & $44,1^{\mathrm{b}} \pm 1,00$ & $41,0^{\mathrm{a} B} \pm 0,10$ & $44,1^{\mathrm{bB}} \pm 1,10$ & $43,6^{b} \pm 0,60$ & 0,00 \\
\hline$a^{*}$ & $0,20^{b B} \pm 0,10$ & $-0,20^{a \mathrm{~B}} \pm 0,10$ & $0,10^{\mathrm{bB}} \pm 0,20$ & $0,30^{b B} \pm 0,10$ & 0,00 \\
\hline$b^{*}$ & $26,7^{\mathrm{bA}} \pm 1,40$ & $19,6^{\mathrm{aA}} \pm 0,80$ & $27,0^{\mathrm{bB}} \pm 1,20$ & $26,9^{\mathrm{bA}} \pm 0,60$ & 0,00 \\
\hline $\mathrm{C}^{*}{ }_{\mathrm{ab}}$ & $26,7^{\mathrm{bA}} \pm 1,40$ & $19,6^{\text {a } \mathrm{A}} \pm 0,80$ & $27,0^{\mathrm{bB}} \pm 1,20$ & $26,9^{\mathrm{bB}} \pm 0,60$ & 0,00 \\
\hline $\mathrm{h}_{\mathrm{ab}}$ & $89,5^{\mathrm{a} A} \pm 0,20$ & $90,5^{\mathrm{bB}} \pm 0,20$ & $89,7^{\mathrm{aA}} \pm 0,40$ & $89,4^{\text {a } A} \pm 0,30$ & 0,00 \\
\hline \multicolumn{6}{|c|}{18 Months } \\
\hline$L^{*}$ & - & $36,5^{\mathrm{aA}} \pm 1,51$ & 35,5 a $A \pm 1,08$ & $42,7 b \pm 0,77$ & 0,00 \\
\hline$a^{*}$ & - & $0,28^{b c} \pm 0,19$ & $-0,09$ a $B \pm 0,19$ & $0,30 \mathrm{~b} B \pm 0,23$ & 0,00 \\
\hline$b^{*}$ & - & $18,2^{\mathrm{aA}} \pm 1,54$ & 18,2 a $A \pm 1,36$ & $25,1 b \mathrm{~b} \pm 0,96$ & 0,00 \\
\hline $\mathrm{C}^{*}{ }_{\mathrm{ab}}$ & - & $18,2^{\mathrm{aA}} \pm 1,85$ & 18,2 a $A \pm 1,36$ & $25,1 b \mathrm{~b} \mathrm{~A} \pm 0,95$ & 0,00 \\
\hline $\mathrm{h}_{\mathrm{ab}}$ & - & $89,1^{\mathrm{ns} A} \pm 0,43$ & $90,3 A \pm 0,73$ & $89,3 A \pm 0,53$ & 0,00 \\
\hline
\end{tabular}

Different small letters in the same row indicate statistically significant differences (Tukey's Test, $p<0.05$ ) among treatments. Different capital letters in the same column indicate stastically significant differences (Tukey's Test, $p<0.05)$ during storage. SD: standard deviation.

in the coordinate to the effects of compaction and homogenization arising from HPP treatment. The chromatic coordinate $b^{*}$ (yellow-blue), after six months of storage, presented statistically significant decreases for the control samples and for those subjected to thermal pasteurization and HPP treatment. In the period from 6 to 18 months of storage only HPP 450MPa treatment showed significant decreases in that parameter. On the other hand, the psycho-physical chromaticity parameter $\left(\mathrm{C}^{*}{ }_{\mathrm{ab}}\right)$ evolved in the same way as the chromatic coordinate $b^{*}$ after six months of storage. From 6 to 18 months of storage only samples treated by HPP showed significant drops in the chromaticity. The samples subjected to thermal treatment presented in general, $b^{*}$ and $\left(C^{*}{ }_{a b}\right)$ values lower than those found in the samples treated by HPP. This could confirm that thermal treatment causes a higher degradation of green pigments that provide coloration to the jam, probably due to an oxidative phenomena, polymerization of polyphenols or microbial degradation (Arroyo et al., 2008; Arroyo et al., 2009). In this sense Oey et al. (2008) pointed out that high hydrostatic pressures have a limited effect on the pigments which are responsible for the color of fruits and vegetables. The $\mathrm{h}_{\mathrm{ab}}$ tone psycho-physical parameter decreases in control samples and in those treated by HPP, while those thermally treated behave in the opposite way. On the day of elaboration, thermal treated jams presented values significantly lower in $\mathrm{L}^{*}, \mathrm{~b}^{*}, \mathrm{C}^{*}{ }_{\mathrm{ab}}$ and $\mathrm{h}_{\mathrm{ab}}$ parameters, with respect to the control samples and those subjected to HPP, and a value significantly higher than after 6 months from preparation. The same differences among control samples and those thermally and HPP processed were found and $L^{*}, b^{*}$ y $C^{*}{ }_{a b}$ parameters showed the same behavior. However, thermal treated jams showed values significantly lower than $a^{*}$ and higher than $\mathrm{C}^{*}{ }_{\mathrm{ab}}$. After 18 months of storage, the processed samples at $600 \mathrm{MPa}$ had higher values than $L^{*}, a^{*}, b^{*}$ y $C^{*}{ }_{a b}$, while no significant differences were found for the $h_{a b}$ value. In the same way, Garcia-Parra et al. (2011) indicated in nectarine puree during storage that the application of high hydrostatic pressure treatments was more stable with respect to colorimetric parameters than in thermal pasteurization treatments. These authors pointed out that the high hydrostatic pressures have a limited effect on the pigments responsible for the color of fruits and vegetables (Oey et al., 2008). After individually analyzing the colorimetric parameters in order to evaluate the colorimetric involvement attributable to the different treatments 
applied to the samples, the respective differences in color in the CIELab space was determined. After 6 months of storage the samples that showed the greatest differences in color were those subjected to thermal treatment $\left(\Delta \mathrm{E}^{*}{ }_{a b}=5.67\right)$ compared with the control samples $\left(\Delta \mathrm{E}^{*}{ }_{\mathrm{ab}}=2.87\right)$; or those subjected to HPP treatment $\left(\Delta \mathrm{E}^{\star}{ }_{a b}=2.71 ; 450 \mathrm{MPa}\right.$; $\Delta \mathrm{E}^{*}{ }_{\mathrm{ab}}=2.89 ; 600 \mathrm{MPa}$ ) which had similar and lower values than 3 units CIELab. Oey et al. (2008) have compiled similar results regarding the effect of HPP on the color, texture and aroma of fruits and vegetables in a bibliographic review. In the period from 6 to 18 months of storage the samples treated with HPP 600MPa presented less color differences $\left(\Delta \mathrm{E}^{*}{ }_{a b}=2.01\right)$ against those obtained by thermal treatment $\left(\Delta \mathrm{E}^{\star}{ }_{\mathrm{ab}}=4.74\right)$ and by $\mathrm{HPP} 450 \mathrm{MPa}$ $\left(\Delta \mathrm{E}^{*}{ }_{\mathrm{ab}}=12.06\right)$. In view of the results obtained, and considering that only $\Delta \mathrm{E}^{*}{ }_{a b}$ values higher than 3 CIELab units represent perceptible differences in color to the human eye (Bodart et al., 2008), it is remarkable that, over 18 months of storage, samples subjected to HPP 600MPa treatment would be the best to retain the colorimetric characteristics of freshly prepared food, with such small differences color that they would not be noticeable by consumers. In accordance with our results, Garcia-Parra et al. (2011) observed, while working with nectarine puree samples, that those subjected to thermal pasteurization treatments showed more intense color changes during storage. Sensory analysis was performed to assess the preference of consumers in the final product evaluating the appearance, texture, aroma and flavor parameters of jams subjected to HPP and thermal pasteurization (Figure 1). The results show a clear trend because different experimental treatments affected the acceptability and the final quality of the product. According to appearance, the HPP $600 \mathrm{MPa}$ treatment obtained a higher score than the HPP 450MPa and thermal treatment. Likewise, the score given by tasters to the texture and flavor was greater in the HPP treatments than in thermal treatment although there were no significant

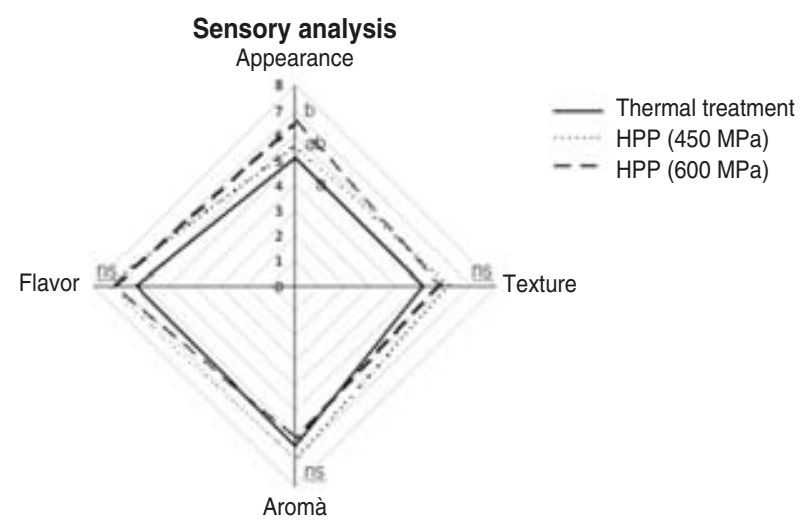

Figure 1

Organoleptic assessment (aspect, flavor, texture and aroma) changes in high pressure and thermal treated olive jam during storage. Different small letters indicate significant statistical differences (Tukey's Test, $p<0.05$ ) among treatments. differences. Kouniaki et al. (2004) and Oey et al. (2008) showed similar results. These researchers indicated that changes in the chemical composition and sensory analysis of food treated with high pressures are lower than the changes observed in those subjected to thermal treatment, with respect to "fresh" or unprocessed foods. Similar results were obtained by several researchers (Sánchez et al., 2012) for olive pate. On the other hand, Schwartz et al. (2009) pointed out that in olive paste treated by thermal pasteurization, temperature and storage did not affect the acceptability or the quality of the product, indicating that it is beneficial since the paste maintains the same acceptability over time and that it can be stored in cold temperatures.

\section{CONCLUSION}

The application of high hydrostatic pressure treatments for the conservation of olive jam is an improvement in thermal treatment quality especially when greater intensity of pressure $(600 \mathrm{MPa})$ treatments are applied, because the presence of microorganisms is reduced to a greater extent. In addition, these jams present greater clarity $\left(\mathrm{L}^{*}\right)$ and, consequently, less browning and less differences in color $\left(\Delta \mathrm{E}^{\star}{ }_{\text {ab }}\right)$, which is a significant improvement in the quality of the final product.

\section{ACKNOWLEDGEMENTS}

This study has been funded by the "Minimally Processed and Healthy Foods (draft dossier: 1904542, Ministry of Science and Innovation)" project (Government of Spain). M.N. Franco would like to thank the FSE and the Government of Extremadura for the (TEC09072) scholarship awarded. R Ramirez thanks ERDF and INIA (BOE 10.01.07) for the contract awarded. They also wish to thank M. García Serrano, J. Hernández Carretero, J.M. García Ballesteros, M.D. Valcarcel Lozano and J. Nogales Barahona for their valuable cooperation in the development of this work.

\section{REFERENCES}

Acín S, Navarro MA, Perona JS, Arbonés-Mainar JM, Surra JC, Guzmán MA. 2007. Olive oil preparation determines the atherosclerotic protection in apolipoprotein e knockout mice. J. Nutr. Biochem. 18, 418-424.

Arroyo-López FN, Bautista-Gallego J, Durán-Quintana MC, Garrido-Fernández A. 2008. Effects of ascorbic acid, sodium metabisulfite and sodium chloride on freshness retention and microbiol growth during the storage of Manzanilla-Aloreña cracked table olives. LWT - Food Sci. Technol. 41, 551-560.

Arroyo-López FN, Bautista-Gallego J, Segovia-Bravo KA, García-García P, Durán-Quintana MC, Romero C, Rodríguez-Gómez F, Garrido-Fernández A. 2009. Instability profile of fresh packed seasoned 
Manzanilla-Aloreña table olives LWT - Food Sci. Technol. 42, 1629-1639.

Asaka M, Aoyama Y, Ritsuko N, Hayashi R. 1994. Purification of a latent form of polyphenoloxidase from la France pear fruit and its pressure activation. Biosci. Biotechnol. Biochem. 58, 1486-1489.

Barbosa-Cánovas GV, Pothakamury UR, Palou E, Swanson BG. 1998. Food Irradiation, Nonthermal preservation of foods, Marcel Dekker Inc., New York, USA. 161-213.

Bodart M, de Peñaranda R, Deneyer, A, Flamant G. 2008. Photometry and colorimetry characterisation of materials in daylighting evaluation tools. Build. Environ. 43, 2046-2058.

Buckow R, Heinz V, Knorr D. 2005. Effect of high hydrostatic pressure temperature combinations on the activity of $\beta$-glucanase from barley malt. J. Inst. Brew. 111, 282-289.

Cancho FG, Rejano L, Borbolla-Alcala JMR. 1980. La formación de ácido propiónico durante la conservación de las aceitunas verdes de mesa. III. Microorganismos responsables. Grasas Aceites, 31, 245-250.

Carlez A, Rosec JP, Richard N, Cheftel JC. 1994. Bacterial growth during chilled storage of pressure-treatment minced meat. Lebensm. Wiss. Tech. 27, 48-54.

Conforti F, Sosa S, Marrelli M, Menichini F, Statti GA, Uzunov D. 2009. The protective ability of Mediterranean dietary plants against the oxidative damage: The role of radical oxygen species in inflammation and the polyphenol, flavonoid and sterol contents. Food Chem. 112, 587-594.

Cheftel JC. 1992. Effect of high hydrostatic pressure on food constituents: An overview, in 20 Balny C, Hayashi R, Heremans K, Masson P (Ed.). High Pressure of Biotechnology, John Libbey 21 Eurotext, Montrouge, 195-209.

CIE. 2004. Colorimetry: technical report CIE15.2, 3rd edn. Vienna, Austria.

De Lamo-Castellví S, Capellas M, López-Pedemonte T, Hernández-Herrero MM, Guamis B, Roig-Sagués AX. 2004. Behaviour of Yersinia enterocolitica strains inoculated in model cheese treated with high hydrostatic pressure. J. Food Prot. 68, 528-533.

Deliza R, Rosenthal A, Abadio FBD, Silva C, Castillo C. 2005. Application of high pressure technology in the fruit juice processing: benefits perceived by consumers. J. Food Eng. 67, 241-246.

EN ISO 6579. 2002. Microbiology of food and animal feeding stuffs. Horizontal method for the detection of Salmonella spp.

EN ISO 11290-1. 1996.Microbiology of food and animal feeding stuffs. Horizontal method for the detection and enumeration of listeria monocytogenes. Part 1: detection method.

García P, Brenes M, Romero C, Garrido A. 1999. Color and texture of acidified ripe olives in pouches. J. Food Sci. 64, 248-251.

García-Parra J, González-Cebrino F, Delgado J, Lozano M, Hernández T, Ramírez R. 2011. Effect of Thermal and High-Pressure processing on the nutritional value and quality attributes of a nectarine purée with industrial origin during the refrigerated storage. $J$. Food Sci. 76, C618-C625.

Hargrove RL, Etherton TD, Pearson TA, Harrison $\mathrm{EH}$, Kris-Etherton PM. 2001. Low fat and high monounsaturated fat diets decrease human low density lipoprotein oxidative susceptibility in vitro. $J$. Nutr. 131, 1758-1763.
Heinitz ML, Johnson JM. 1998. The incidence of Listeria spp., Salmonella spp. and Clostridium botulinum in smoked fish and shellfish. J. Food Protec. 61, 318323.

Hendrickx M, Ludikhuyze L, Van den Broek I, Weemaes C. 1998. Effects of high pressure on enzymes related to food quality. Trends Food Sci. Technol. 9, 197-203.

Heremans K, Smeller L. 1998. Protein structure and dynamics at high pressure. Biochim. Biophys. Acta 1386, 353-370

Hite $\mathrm{BH}$. 1899. The effect of pressure in the preservation of milk. Bulletin of West Virginia University Agricultural Experiment Station 58, 15-35.

ISO 4833. 1991. Microbiology of food and animal feeding stuffs - Horizontal method for the enumeration of microorganisms - Colony-count technique at 30 degrees $\mathrm{C}$.

ISO 7954. 1988. Microbiology- General Guidance for enumeration of yeasts and moulds- Colony count technique al $25^{\circ} \mathrm{C}$.

ISO 8586-2. 2008. Guía general para la selección, entrenamiento y control de evaluadores. Parte 2: Evaluadores sensoriales expertos. International Organitation for Standardization, Genève, Switzerland.

ISO 8589. 2007. Análisis sensorial. Guía general para el diseño de salas de catas. International Organitation for Standardization, Genève, Switzerland.

Kalua C, Bedgood D, Bishop A, Prenzler P. 2008. Changes in virgin olive oil quality during lowtemperature fruit storage. J. Agric. Food. Chem. 56, 2415-2422.

Kalua CM, Allen MS, Bedgood Jr DR, Bishop AG, Prenzler PD, Robards K. 2007. Olive oil volatile compounds, flavour development and quality: A critical review. Food Chem. 100, 273-286.

Kouniaki S, Kajda P, Zabetakis I. 2004. The effect of high hydrostatic pressure on anthocyanins and ascorbic acid in blackcurrants (Ribes nigrum). Flavour Fragance J. 19, 281-286.

Krebbers B, Matser AM, Hoogerwerf SW, Moezelarr R, Tomassen MMM, van der Berg RW. 32003. Combined high-pressure and thermal treatments for processing of tomato puree: valuation of microbial inactivation and quality parameters. Innovative Food Sci. Emerg. Technol. 4, 377-385.

Mclnerney JK, Cathryn A, Seccafien C, Stewart CM, Bird AR. 2007. Effects of high pressure processing on antioxidant activity, and total carotenoid content and availability, in vegetables. Innovative Food Sci. Emerg. Technol. 8, 543-548.

Mor-Mur M. 2010. Alimentos tratados por alta presión. Aspectos nutricionales. Actividad Dietética 14, 53-58.

Oey I, Lille M, Van Loey A, Hendrickx M. 2008. Effect of high pressure processing on colour, texture and flavour of fruits and vegetables bases food products. Trends Food Sci. Technol. 19, 320-328.

Oey I, Van der Plancken I, Van Loey A, Hendrickx M, 2007. Does high pressure processing influence nutritional aspects of plant based food systems? Trends Food Sci. Technol. 19, 300-308.

Pascual-Anderson R, Calderón-Pascual V. 2000. Microbiología alimentaria. Metodología analítica para alimentos y bebidas. Díaz de Santos, S.A, $2^{\underline{a}}$ edición, Madrid (España), 117-119.

Patterson MF, Margey DM, Mills G, Simpson R, Glimour A. 1997. The effect of high pressure treatment on microorganisms in foods. High Pressure Research, in the Bioscincesand Biothecnology, K. Heremans, (Ed.) Leuven University Press. Leuven, Belgium, 269-272. 
Patterson MF. 2005. Microbiology of pressure-treated foods. J. Appl. Microbiol. 98, 1400-1409.

Rastogi NK, Rraghavarao KSMS, Nirajan K. 2005 Developments in osmotic dehydration, en Sun DW (Ed.) Emerging technologies for food processing. Elservier, London, 221-249.

Reglero G, Señorans FJ, Ibáñez E. 2005. Supercritical fluid extraction: an alternative to isolating natural food preservatives, en Barbosa-Cánovas GV, Tapia MS, Cano MP. (Ed.). Novel food procesing technologies, CRC Press, New York, 539-553.

Sánchez J, De Miguel C, Ramírez MR, Delgado J, Franco MN, Martín D. 2012. Efecto de las altas presiones hidrostáticas respecto a la pasteurización térmica en los aspectos microbiológicos, sensoriales y estabilidad oxidativa de un paté de aceituna. Grasas Aceites 63, 100-108.

Schwartz M, Quitral V, Daccarett C, Callejas J. 2009. Desarrollo de pasta untable de aceituna variedad Sevillana. Grasas Aceites 60, 451-457.

Schwartz M, Quitral V, Daccarett C, Callejas R. 2011. Efecto de la adición de ajo en la estabilidad y calidad sensorial de una pasta de aceituna. Grasas Aceites 62, 337-343.

Soliva-Fortuny R, Balasa A, Knorr D, Martín-Belloso O. 2009. Effects of pulsed electric fields on bioactive compounds in foods: a review. Trends Food Sci. Technol. 20, 544- 556.

Tewari G, Jayas DS, Holley RA. 1999. High pressure processing of foods: an overview. Sciences des Aliments 19, 619-661.

Wilson DR, Dabrowski L, Stringer S, Moezelaar R, Brocklehurst TF. 2008. High pressure in combination with elevated temperature as a method for the sterilisation of food. Trends Food Sci. Technol. 19, 289-299.

Wolbang CM, Fitos JL, Treeby MT. 2008. The effect of high pressure processing on nutritional value and quality attributes of Cucumis melo L. Original Research Article. Innovative Food Sci. Emerg. Technol. 9, 196-200.

Recibido: 5/2/13 Aceptado: 22/4/13 